\title{
Cytokine expression profile in hamsters immunized with OmpL37 from Leptospirainterrogans in different vaccine formulations
}

\author{
Thaís Oliveira 1* André Grassmann², Rodrigo Schuch¹, Mariana Pereira', Daiane Hartwig ${ }^{3}$, Alan McBride², \\ Odir Dellagostin ${ }^{1}$
}

From 5th Congress of the Brazilian Biotechnology Society (SBBIOTEC)

Florianópolis, Brazil. 10-14 November 2013

\section{Background}

Pathogenic spirochetes from the genus Leptospira are the bacteria that cause leptospirosis, an emerging zoonosis responsible for over 500,000 human cases each year [1]. Vaccination with inactivated whole-cell preparations (bacterins) has limited efficacy due to the wide antigenic variation of the pathogen. Bacterins are reactogenic and confers serovar specific and short-term immunity [2]. The protein OmpL37 represents a potential target for vaccine development against leptospirosis since it is recognized by human and animal serum, binds human extracellular matrix components, is up-regulated in vivo and conserved among pathogenic leptospires [3]. We aimed to evaluate the immune response induced by OmpL37 from L. interrogans serovar Copenhageni strain Fiocruz L1-130 in hamsters, using prime-boost, DNA, and protein-based immunizations.

\section{Methods}

The ompL37 gene was cloned into pAE and pTargeT vectors, to obtain a subunit and a DNA vaccine, respectively. The recombinant protein OmpL37 (rOmpL37) was characterized by Western blot (WB) and pTargeT/ompL37 was evaluated by transfection of CHO-K1 cells and analyzed by immunofluorescence. Groups of 6 hamsters were immunized twice with an interval of 21 days as follows: rOmpL37-Alhydrogel (2x $100 \mu \mathrm{g})$, pTargeT-ompL37 (2x $100 \mu \mathrm{g})$, prime-boost pTargeT-ompL37 $(100 \mu \mathrm{g})$ plus

'Laboratório de Vacinologia, Unidade de Biotecnologia, CDTec, Universidade Federal de Pelotas, Pelotas, RS, Brazil

Full list of author information is available at the end of the article
rOmpL37 $(100 \mu \mathrm{g})$, pTargeT $(2 \mathrm{x} 100 \mu \mathrm{g})$ and PBSAlhydrogel. Two independent experiments were conducted. Pooled blood samples, collected at days 0, 21 and 42, were processed for RNA isolation using the RiboPureBlood Kit (Ambion). cDNA synthesis was performed using the High-Capacity cDNA Reverse Transcription Kits (Applied Biosystems). Expression profiles of IFN- $\gamma$, TNF$\alpha$, IL1- $\alpha$ and TGF- $\beta$ were accessed by quantitative realtime PCR using SYBR Green PCR Master Mix (Applied Biosystems). The relative $\mathrm{Ct}\left(\Delta \Delta \mathrm{C}_{\mathrm{T}}\right)$ method was used to quantify cytokine gene expression. The CT of each test gene was evaluated in pooled hamster whole-blood samples, the CTs were normalized against the $\beta$-actin gene $\mathrm{CT}(\triangle \mathrm{CT})$ and then compared to the same normalized gene in the respective control groups (calibrator) [4].

\section{Results and conclusion}

Considering that target genes are up or down-regulated when a 2-fold change in mRNA levels is observed [5], TNF- $\alpha$ was induced by rOmpL37 at day $42($ ratio $=2.84)$, and by pTargeT/ompL37 at days 21 and 42 (ratio $>5$ ). In contrast, IFN- $\gamma$ was down regulated in the prime-boost group at day $42($ ratio $=0.41)$. Similarly, down-regulation of IL1- $\alpha$ was observed at day 42 in the pTargeT/ompL37 $($ ratio $=0.28)$ and prime-boost $($ ratio $=0.19)$ groups. TGF- $\beta$ was expressed at basal levels in all groups. Both rOmpL37 and pTargeT/ompL37 were able to induce a pro-inflammatory response, characterized by increased TNF- $\alpha$ expression. However, the Th1 and pro-inflammatory cytokine levels decreased in the prime-boost group. 


\section{Acknowledgements}

CNPq, CAPES and FAPERGS.

\section{Authors' details}

'Laboratório de Vacinologia, Unidade de Biotecnologia, CDTec, Universidade Federal de Pelotas, Pelotas, RS, Brazil. "2Laboratório de Pesquisa em Doenças Infecciosas, Unidade de Biotecnologia, CDTec, Universidade Federal de Pelotas, Pelotas, RS, Brazil. '3Departamento de Microbiologia e Parasitologia, Instituto de Biologia, Universidade Federal de Pelotas, Pelotas, RS, Brazil.

Published: 1 October 2014

\section{References}

1. Adler B, de de la Peña Moctezuma A: Leptospira and leptospirosis. Veterinary Microbiology 2010, 140(3-4):287-296, doi:10.1016/j. vetmic.2009.03.012.

2. Dellagostin OA, Grassmann AA, Hartwig DD, Félix SR, da Silva ÉF, McBride AJ: Recombinant vaccines against Leptospirosis. Human Vaccines 2011, 7(11):1215-1224, doi: 10.4161/hv.7.11.17944.

3. Pinne M, Choy HA, Haake DA: The OmpL37 surface-exposed protein is expressed by pathogenic Leptospira during infection and binds skin and vascular elastin. PLoS Negl Trop Dis 2010, 4(9):e815, doi:10.1371/journal. pntd.0000815.

4. Livak KJ, Schmittgen TD: Analysis of relative gene expression data using real-time quantitative PCR and the 2(-Delta Delta $C(T))$ Method. Methods 2001, 25(4):402-408, doi:10.1006/meth.2001.1262.

5. Vernel-Pauillac F, Goarant C: Differential cytokine gene expression according to outcome in a hamster model of leptospirosis. PLOS Negl Trop Dis 2010, 4(1):e582, doi:10.1371/journal.pntd.0000582.

doi:10.1186/1753-6561-8-S4-P164

Cite this article as: Oliveira et al: Cytokine expression profile in hamsters immunized with OmpL37 from Leptospirainterrogans in different vaccine formulations. BMC Proceedings 2014 8(Suppl 4):P164.

\section{Submit your next manuscript to BioMed Central} and take full advantage of:

- Convenient online submission

- Thorough peer review

- No space constraints or color figure charges

- Immediate publication on acceptance

- Inclusion in PubMed, CAS, Scopus and Google Scholar

- Research which is freely available for redistribution

Submit your manuscript at www.biomedcentral.com/submit
C Biomed Central 